\title{
Article
}

\section{The effect of medical history and compressor on barotrauma}

\author{
Asti Melani Astari, ${ }^{1}$ Fatimah, ${ }^{2}$ Sri Andarini ${ }^{3,4}$ \\ ${ }^{1}$ School of Nursing, Faculty of Medicine, Universitas Brawijaya, Malang; ${ }^{2}$ Health Polytechnic Ministry of Health \\ in Jayapura, D3 Nursing Study Program in Nabire; ${ }^{3}$ Faculty of Medicine, Universitas Brawijaya, Malang; \\ ${ }^{4}$ Academic hospital of Universitas Brawijaya, Malang, Indonesia
}

\begin{abstract}
Background: Barotrauma causes damage to an enclosed cavity within the human body due to pressure changes inside and outside the body. This research aims to identify the effect of medical history and compressor on barotrauma.

Design and method: The case-control design and total sampling methods were used to obtained data from 174 respondents.

Results: The bivariate result showed that the value of medical history was at $\mathrm{p}=0.006, \mathrm{OR}=2.47$, with a compressor value of $\mathrm{p}=0.000, \mathrm{OR}=16.29$. Furthermore, the multivariate analysis indicated that the compressor has a dominant factor at $\mathrm{OR}=17.175$.

Conclusions: Both medical history and compressor affected barotrauma incidence, with compressor as the most dominant factor.
\end{abstract}

\section{Introduction}

Barotrauma is a medical problem caused by the barometric difference between physiological pressure inside and outside the body, which leads to damage in tissues of enclosed cavities, such as the middle ear, paranasal sinuses, and lungs. ${ }^{1}$ Barotrauma is common in sea diving, ${ }^{2}$ and study has shown that the global incidence of barotrauma is 35 out of 10.000 dives using diving apparatus, with a mortality rate of 130 out of 10,000 cases. $^{2}$ This occurrence of this disease is considered high in Indonesia. A study carried out in 2012, reported 24 incidences of barotrauma out of a total of 74 traditional divers. ${ }^{3}$ Another study in 2016 found that bleeding occurred in various body organs and tissues of $41.37 \%$ of traditional divers due to sudden changes in air pressure. ${ }^{4,5}$ Furthermore, $6.91 \%$ of traditional divers experienced problems with their nervous, digestive, cardiovascular system, joints, lungs, and skin. ${ }^{4}$ Barotrauma is caused by a few factors, such as medical history and the use of unsafe/sub-standard breathing apparatus. It is known that medical history of hypertension, asthma, vascular diseases, lung problems, ear infection, and heart disease increases barotrauma risk. ${ }^{6}$ Although partial blockage of auditory canal, otitis media, and control asthma and sinusitis also lead to barotrau- ma, divers with these health problems can still carry out their diving activities. 7,8

Another factor contributing to the occurrence of barotrauma is the use of breathing apparatus. According to study, Scuba's activity, which is common during diving, is not safe or does not follow the standard operating procedure (SOP).${ }^{9}$ Therefore it leads to the occurrence of barotrauma. Generally, traditional fisherman-divers of Tasipi Island of West Muna Regency, Southeast Sulawesi, Indonesia, rely on air compressors during their dives. Some of these fishermen use those manufactured in the automotive, shipyard industry, and workshop, which consists of a compressor machine, a hose, and a regulator.

During diving activities reciprocating compressors bank were used to pump in and out the gas inhaled and exhaled through the diver's helmet. ${ }^{10}$ In general, this compressor sucks air from the atmosphere with a mixture of several gases, namely $78 \%$ nitrogen, $21 \%$ oxygen and $1 \%$ mixture of argon, carbon dioxide, water vapor, oil and others. Indonesian Government restrict the uses of diving compressors that use gasoline due to its risk of carbonmonoxy intoxication to divers. ${ }^{11}$ Sub standardized breathing equipment in diving not only infringe safety procedure but also increasing the risk of gas intoxication which damage the body tissue. ${ }^{12}$

The use of such compressors is considered dangerous because they do not meet the diving safety standard. The danger also comes from the fact that the air supply inhaled by the fishermen during the dives depends on the air compressor's reliability on the boat. A compressor that stops working or air hose that becomes twisted from the regulator during a dive tends to disturb the diver's air. The outcome of such incidences is certainly fatal. ${ }^{13} \mathrm{~A}$ preliminary study carried out using 87 traditional divers with barotrauma showed three divers had barotrauma-related paralysis. When interviewed, 10 out of the 87 divers stated that they did not regard barotrauma as a medical problem that required immediate intervention, rather as a problem related to local belief (superstition), which is embraced by the people. The study showed that 8 out of 10 traditional divers had a medical history of asthma and hearing problems with uncontrolled treatment. Therefore, this study aims to identify the effect of medical history and compressor on the incidence of barotrauma.

Significance for public health

Barotrauma causes damage to the enclosed cavity within the human body due to changes in pressure inside and outside the body. The incidence of barotrauma in Indonesia is high, with medical history and compressor among the common factors affecting its existence. This research describes the effect of medical history and compressor on barotrauma. 


\section{Design and Methods}

This is an observational and analytical research with the casecontrol approach and total sampling techniques used to obtain data from 174 traditional fishermen divers. The study was carried out from $23^{\text {rd }}$ November to $5^{\text {th }}$ December 2018 in Tasipi Island using an observation sheet as the research instrument. Bivariate analysis was carried out using chi-square and Fisher's exact test to identify the effect of medical history and compressor on barotrauma. Meanwhile, multivariate analysis was conducted with a logistic regression test to identify the contributing factor that is more dominant in the incidence of barotrauma. The study was carried out after obtaining ethical clearance number 2504/UN29.20/PPM/2018 from the ethical commission of the research and community service unit of Halu Oleo University (LPPM UHO).

\section{Results and Discussions}

Table 1 shows that the youngest, oldest, and mean ages in the barotrauma group were 16, 67, and 45.93 years old. Meanwhile, the youngest, oldest, and mean ages in non-barotrauma were 19 , 61, and 39.38 years old. Table 2 shows the result of univariate analysis concerning medical history. The number of traditional divers from the barotrauma group is higher than those without medical history at values of 59 and 28, respectively. Meanwhile, the number of traditional divers without medical history from the non-barotrauma group was slightly higher than those with medical history from the same group at values of 47 and 40 respondents, respectively.

Regarding the compressor variable, in the barotrauma group, the number of traditional divers that used compressor was overwhelmingly higher ( 84 respondents) than those that did not use compressors ( 3 respondents). In the non-barotrauma group, the number of traditional divers that used barotrauma was also significantly higher (with 55 respondents) than those that did not use the tool. The bivariate analysis result shows that the value of the medical history variable was at $\mathrm{p}=0.006(\mathrm{p}<0.05)$ and $\mathrm{OR}=2.47$. Therefore, it can be concluded that medical history had an effect on barotrauma incidence among the fisherman-traditional divers of Tasipi island of West Muna Regency, Southeast Sulawesi. Furthermore, those with medical history were 2.47 times at risk of barotrauma than those without medical history.

In addition, the value of compressor variable was at $\mathrm{p}=0.000$ $(\mathrm{p}<0.05)$ and $\mathrm{OR}=16.29$. This suggests that compressor had an effect on barotrauma incidence among the fisherman-traditional divers of Tasipi island of West Muna regency, Southeast Sulawesi; those using compressors were 16.29 times at risk of barotrauma than those that did not use the tool.

The study's result indicates that medical history affects barotrauma among the traditional fisherman-divers of Tasipi island of
Muna Regency, Southeast Sulawesi, with $\mathrm{p}=0.006$. Divers with medical history were 2.47 times at risk of barotrauma than those without medical history. On average, the divers that experienced barotrauma had histories of asthma, lung diseases, and hypertension. Those with asthma as the most common accompanying health problems were 43 divers $(50 \%)$. In divers suffering from asthma, barotrauma experience worsens their health condition ranging from difficulty in urinating to paralysis. The research showed that paralysis occurred in 15 respondents, three of whom were with total paralysis.

This research is in line with the study carried out, ${ }^{6,13}$ which stated that medical history of hypertension, asthma, lung problems, heart diseases, and ear infection tend to increase the risk of barotrauma. ${ }^{6}$ Traditional fishermen-divers tend to have lower lung capacity than normal people due to increased air pressure during diving. Divers with a history of heart disease and hypertension who experience barotrauma can worsen their body condition. Fishermen who dive often experienced dizziness or vertigo during and after finished diving. Palpitations and shortness of breath before or after diving were also additional syndrome experienced by fisherman divers. Furthermore about 26 people also had lung infections such as pneumonia and otitis media.

The history of comorbid hypertension has been shown to affect the poor quality of life of traditional divers with decompression sickness. The multivariate result that there is a history of comorbid hypertension has a large risk of 65,476 times greater for bad quality of life than those without a history of comorbid hypertension. ${ }^{14}$ People with asthma also have limited lung capacity makes it difficult for divers to hold their breath for a long time. When such divers force themselves to keep diving, they put themselves at higher risk of barotrauma. ${ }^{6}$ Mandatory health requirement for diving is rather rigid compare to other sports. Based on physical assessment guideline for scuba divers which describes both relative and absolute contraindication, that include people with asthma are restricted to diving practice.

On the other hand, other potential divers with asthma should be evaluated individually to reflect their diving fitness level this includes the type and severity of asthma, life history of asthma attacks, and what can trigger an asthma attack. Divers with a history of asthma before deciding to go underwater, should see a special diver doctor and undergo routine lung examinations. ${ }^{7,8}$ The increasing risk of decompression also decrease the diver's health status and quality of life. ${ }^{15}$ Divers who have a previous history of decompression sickness are at risk for relapse of decompression sickness because the body's ability to compensate for the lungs air

Table 1. Barotrauma vs non-barotrauma.

\begin{tabular}{lcccc} 
Group & Mean & Min & Max & SD \\
Barotrauma & 45.93 & 16 & 67 & 12.90 \\
Non-barotrauma & 39.38 & 19 & 61 & 11.00 \\
\hline
\end{tabular}

Table 2. Crosstabulation analysis.

\begin{tabular}{|c|c|c|c|c|c|c|c|}
\hline \multirow[t]{3}{*}{ Variables } & \multirow[t]{3}{*}{ Categories } & \multicolumn{4}{|c|}{ Group } & \multirow[t]{3}{*}{ p-value } & \multirow[t]{3}{*}{ OR } \\
\hline & & \multicolumn{2}{|c|}{ Barotrauma } & \multicolumn{2}{|c|}{ Non-barotrauma } & & \\
\hline & & f & $\%$ & f & $\%$ & & \\
\hline \multirow[t]{2}{*}{ Medical history } & Yes & 59 & 33.9 & 40 & 23 & \multirow[t]{2}{*}{0.006} & \multirow[t]{2}{*}{2.47} \\
\hline & No & 28 & 16.1 & 47 & 27 & & \\
\hline \multirow[t]{2}{*}{ Compressor } & Use & 84 & 48.3 & 55 & 31.6 & \multirow[t]{2}{*}{0.000} & \multirow[t]{2}{*}{16.29} \\
\hline & Do not use & 3 & 1.7 & 32 & 18.4 & & \\
\hline
\end{tabular}


bubble formation is reduced. ${ }^{16}$ Another finding of the study is that the use of compressor has an effect on the incidence of barotrauma among the traditional fisherman-divers of Tasipi island with $p=0.000$. Divers that make use of compressors when diving was 16.29 times at risk of barotrauma than those that did not use the tool. ${ }^{17}$ The result of the multivariate analysis shows that compressor was a more dominant factor in the incidence of barotrauma with $\operatorname{Exp}$ (B) 17.157, after being controlled by medical history (Table 3).

The compressors that Tasipi traditional fisherman-divers commonly used are the same ones employed by automotive or shipyard industries. Therefore, they are not specifically designed for diving. This is because these compressors did not have an air filter to adjust the amount of air that entered the body. Hence using them during diving puts these fisherman-divers in a dangerous situation since the absence of such filter leads to nitrogen poisoning and oxygen toxicity, thereby causing barotrauma, which damages organs and tissues, especially in the lungs and ears. ${ }^{6,9}$ Pai and Shetty also maintained that sub-standard diving apparatus leads to barotrauma because using these tools subjects the divers' body to excessive pressure. ${ }^{8}$ Furthermore, the hazard of using sub-standard compressors was underlined ${ }^{9}$ by suggesting that such compressors were dangerous for Tasipi fisherman-divers because the supply of air for the divers depends on the reliability of compressors on the boat. When the compressors fail to work or the hose becomes twisted or leaking, the vital air supply becomes disrupted, which becomes fatal for divers. Asides from divers, barotrauma is also common among those that use compressors in the industrial context. Such barotrauma often occurs in the form of perforation of the sigmoid colon, ${ }^{18}$ which is caused by an increase in pressure inside the body, especially in the gastrointestinal tract, thereby causing (abdominal) pain and distention. Abdominal distention puts pressure on the colon, which leads to rectal perforation. ${ }^{19}$

Furthermore, the high incidence of barotrauma among traditional fisherman-divers of Tasipi island is exacerbated by their lack of knowledge concerning the danger of using sub-standard compressors and the importance of diving safety. The fishermandivers' low awareness of the importance of diving safety standards is due to the absence of education from relevant local government agencies, particularly the Ministry of Maritime Affairs and Fisheries and the Ministry of Health. In other words, no coordination between the two ministries is one of the contributing factors of barotrauma incidence among the traditional fisherman-divers in Tasipi Island. The high incidence of barotrauma is caused by the absence of protective equipment and the use of compressors that were not modified to meet diving safety standards. ${ }^{20-22}$

Tasipi traditional fisherman-divers that showed symptoms of barotrauma did not seek immediate medical treatments partly because they believed that the disease was not medical in nature, rather, they addressed it as a problem associated with supernatural beings. With the absence of the right medical intervention, barotrauma leads to partial and permanent paralysis. ${ }^{23-25}$ According to Cialoni barotrauma need to be treated with the inception of the early appearance of its symptoms such as hearing or breathing difficulty to avoid complications, such as paralysis. ${ }^{6}$

Table 3. Multivariate logistic regression.

\begin{tabular}{lcc} 
Variables & p-value & Exp (B) \\
Medical history & 0.005 & 2.668 \\
Compressor & 0.000 & 17.157 \\
\hline
\end{tabular}

\section{Conclusions}

The incidence of barotrauma is commonly affected by medical history and compressors, although compressors are more dominant variables. Although, government has set law and regulation as safety measures to prevents barotrauma, the implementation still under scrutiny. Government also needs to provide counseling on diseases related to dive-fishing activities to improve divers' knowledge and information for occupational diseases prevention program. Self-awareness of divers to check their physical fitness, standardized equipment and self-control to only dive to their level of training and comfort are important components to prevent barotrauma at individual level.

Correspondence: Asti Melani Astari, School of Nursing, Faculty of Medicine, Universitas Brawijaya, Jl. Puncak Dieng, Kunci, Kalisongo, Kec. Dau, Malang, East Java Indonesia 65151.

Tel. +62.341569117 - Fax: +62.341564755 .

E-mail: astariasti.fk@ub.ac.id

Key words: Medical history; compressor; barotrauma.

Contributions: All authors contributed equally to this article.

Conflict of interests: The authors declared no potential conflict of interest.

Funding: This study was financially supported by the Faculty of Medicine, Universitas Brawijaya, Malang, Indonesia.

Acknowledgment: The author is grateful to the traditional divers Tasipi Island Indonesia for their support and assistance during this study.

Ethical approval: This study was approved by the health research ethics committee of The Research and Community Service Unit of Halu Oleo University (LPPM UHO).

Conference presentation: Part of this study was presented at the $1^{\text {st }}$ International Nursing and Health Sciences Symposium, November $13^{\text {th }}$ to $15^{\text {th }} 2020$, Brawijaya University, Malang, Indonesia.

Received for publication: 20 January 2021.

Accepted for publication: 22 March 2021.

oCopyright: the Author(s), 2021

Licensee PAGEPress, Italy

Journal of Public Health Research 2021;10:2163

doi:10.4081/jphr.2021.2163

This work is licensed under a Creative Commons Attribution NonCommercial 4.0 License (CC BY-NC 4.0).

\section{References}

1. Navisah SF, Ma'rufi I, Sujoso ADP. [Faktor Risiko Barotrauma Telinga pada Nelayan Penyelam di Dusun Watu Ulo Desa Sumberejo Kecamatan Ambulu Kabupaten Jember (Risk factors of ear barotrauma for fishermen divers in Watu Ulo Hamlet, Sumberejo Village, Ambulu District, Jember Regency)].[Article in Indonesian]. Jurnal IKESMA 2016;12:98-112.

2. Buzzacott PL. The epidemiology of injury in scuba diving. 
Med Sport Sci 2012;58:57-79.

3. Prasetyo AT, Soemantri JB, Lukmantya. Pengaruh kedalaman dan lama menyelam terhadap ambang-dengar penyelam tradisional dengan barotrauma telinga (Effect of depth and length of dives on the hearing threshold of traditional diver with ear barotrauma)].[Article in Indonesian]. ORLI 2012;42:69-76.

4. Sukbar S, Dupai L, Munandar S. [Hubungan Aktivitas Penyelam Dengan Kapasitas Vital Paru Pada Pekerja Nelatan Di Desa Torobulu Kecamatan Laeya Kabupaten Konawe Selatan Tahun 2016 (The relationship between diver activities and vital lung capacity in nelatan workers in Torobulu Village, Laeya District, Konawe Selatan Regency, 2016)].[Article in Indonesian]. Jurnal Ilmiah Mahasiswa Kesehatan Masyarakat 2016;1:1-9.

5. Barron E. The "squeeze," an interesting case of mask barotrauma. Air Med J 2018;37:74-5.

6. Cialoni D, Pieri M, Balestra C, et al. Dive risk factors, gas bubble formation, and decompression illness in recreational SCUBA diving: Analysis of DAN Europe DSL data base. Front Psychol 2017;8:1587.

7. Eichhorn L, Leyk D. Diving medicine in clinical practice. Dtsch Arztebl Int 2015;112:147-58.

8. Battisti AS, Haftel A, Murphy-Lavoie HM. Barotrauma. In: StatPearls [Internet]. Treasure Island: StatPearls Publishing; 2020. Available from: https://www.ncbi.nlm.nih.gov/books/NBK482348/

9. Pai V, Shetty S. Fatal recto-sigmoid rupture by compressed air. Egypt J Forensic Sci 2016;6:542-5.

10. Russeng SS, Saleh LM, Awaluddin M, et al. Intervention model for barotrauma diseases to improve health and safety diving behaviors in traditional fishermen in small islands in Makassar, Indonesia. Sys Rev Pharm 2020;11:597-600.

11. Lee YI, Ye BJ. Underwater and hyperbaric medicine as a branch of occupational and environmental medicine. Ann Occup Environ Med 2013;25:39.

12. Indonesian Government. Fishing Act No. 45 Year 2009. Jakarta: Indonesian Government; 2009.

13. Luthfi OM, Yamindago A, Dewi CSU. [Perbaikan standar keamanan penyelaman nelayan kompresor kondang merak, malang dengan penggunaan scuba (Diving technic improvement of compressor diver at Kondang Merak, Malang using scuba)].[Article in Indonesian]. J Innov Appl Technol
2015;1:165-9.

14. Widyastuti SR, Hadisaputro S, Munasik M. Diving exposure effect on traditional divers's quality of life with decompression sickness. Int J Public Health Clin Sci 2019;6:94-106.

15. Irgens $\AA$, Troland K, Djurhuus R, et al. Diving exposure and health effects in divers working in different areas of professional diving. Int Marit Health 2016;67:235-42.

16. Rusoke-Dierich O. Decompression illness (DCI). In: Diving medicine. Queensland: Springer; 2018.

17. Jansen S, Meyer MF, Boor M, et al. Prevalence of barotrauma in recreational scuba divers after repetitive saltwater dives. Otol Neurotol 2016;37:1325-31.

18. Al-Ozaibi L, Al-Jarrah Z. Colorectal injury by compressed air: the rule of conservative therapy. J Coloproctol 2017;37:47-9.

19. Hazar E, Kayipmaz AE, Coskun A, et al. A dangerous joke: Colon perforation by an air compressor. Med Sci Discov 2015;2:314-3.

20. Hammerton Z. Low-impact diver training in management of SCUBA diver impacts. J Ecotour 2017;16:69-94.

21. Prasetiyo. [Hubungan Perilaku Menyelam Dengan Kejadian Penyakit Dekompresi Pada Penyelam Tradisional di Pulau Lae-Lae Kota Makasar Tahun 2015 (The relationship between diving behavior and the incidence of decompression disease in traditional divers on Lae-Lae Island, Makassar City, 2015)].[Dissertation in Indonesian]. Makassar: Universitas Hassanudin; 2015.

22. Rahmadayanti R, Budiyono B, Darundiati YH. [Faktor resiko gangguan akibat penyelaman pada penyelam tradisional di Karimunjawa Jepara (Risk factors for disruption due to diving in traditional divers in Karimunjawa, Jepara)].[Article in Indonesian]. Jurnal Kesehatan Masyarakat 2017;5:473-81.

23. Pieterse I. The hearing abilities and middle ear functioning of the recreational scuba diver. Dissertation, University of Pretoria; 2006.

24. Jackson CG, von Doersten PG. The facial nerve: current trends in diagnosis, treatment, and rehabilitation. Med Clin North Am 1999;83:179-95.

25. Anderson W, Murray P, Hertweck K. Dive medicine: current perspectives and future directions. Curr Sports Med Rep 2019;18:129-35. 